\title{
NG2-Positive Oligodendrocyte Progenitor Cells in Adult Human Brain and Multiple Sclerosis Lesions
}

\author{
Ansi Chang, ${ }^{1}$ Akiko Nishiyama, ${ }^{2}$ John Peterson, ${ }^{1,4}$ John Prineas, ${ }^{3}$ and Bruce D. Trapp ${ }^{1,4}$ \\ 1Department of Neurosciences, The Lerner Research Institute, The Cleveland Clinic Foundation, Cleveland, Ohio 44195, \\ 2Department of Physiology and Neurobiology, University of Connecticut, Storrs, Connecticut 06269, ${ }^{3}$ Department of \\ Medicine, University of Sydney, Sydney, Australia, and ${ }^{4}$ Neurosciences Graduate Studies Program and Department of \\ Neurosciences, The Ohio State University, Columbus, Ohio 43210
}

\begin{abstract}
Multiple sclerosis (MS) is characterized by multifocal loss of myelin, oligodendrocytes, and axons. Potential MS therapies include enhancement of remyelination by transplantation or manipulation of endogenous oligodendrocyte progenitor cells. Characteristics of endogenous oligodendrocyte progenitors in normal human brain and in MS lesions have not been studied extensively. This report describes the distribution of cells in sections from normal adult human brain and MS lesions by using antibodies directed against NG2, an integral membrane chondroitin sulfate proteoglycan expressed by oligodendrocyte progenitor cells. Stellate-shaped NG2-positive cells were detected in the white and gray matter of normal adult human brain and appeared as abundant as, but distinct from, astrocytes, oligodendrocytes, and microglia. Stellate-shaped or elongated NG2-
\end{abstract}

positive cells also were detected in chronic MS lesions. A subpopulation of the elongated NG2-positive cells expressed the putative apoptotic signaling molecule $p 75^{\mathrm{NTR}}$. TUNEL-positive cells in three active, nine chronic active, and four chronic inactive lesions, however, were $\mathrm{p} 75^{\mathrm{NTR}}$-negative. These studies identify cells with phenotypic markers of endogenous oligodendrocyte progenitors in the mature human CNS and suggest that functional subpopulations of NG2-positive cells exist in MS lesions. Endogenous oligodendrocyte progenitor cells may represent a viable target for future therapies intended to enhance remyelination in MS patients.

Key words: oligodendrocyte progenitor cells; multiple sclerosis; remyelination; NG2; p75 NTR; apoptosis
Multiple sclerosis is an inflammatory demyelinating disease of the human CNS and a major cause of neurological disability among adults in North America and Europe. Pathological changes contributing to neurological disability include inflammation, demyelination, oligodendrocyte death, and axonal degeneration (Raine, 1994; Ferguson et al., 1997; Prineas and McDonald, 1997; Trapp et al., 1999). During early stages of MS extensive remyelination of some lesions can occur (Lassman, 1983) and may contribute to neurological improvement during remissions (Waxman, 1996). Oligodendrocytes have been detected in subacute MS lesions before remyelination (Prineas et al., 1989; Ozawa et al., 1994) and in remyelinating MS lesions (Raine et al., 1981). Although the source of these cells is unknown, studies of experimental demyelination indicate that remyelination in vivo requires the local generation of new oligodendrocytes (Keirstead and Blakemore, 1997). Failure of remyelination in MS could result from the death of oligodendrocyte progenitors. Recent studies have raised the possibility that apoptotic death of oligodendrocyte lineage cells may be mediated via intracellular signaling after activation of the $\mathrm{p} 75^{\mathrm{NTR}}$ receptor, a member of the neurotrophin receptor (NTR) family (CasacciaBonnefil et al., 1996; Dowling et al., 1999).

Previous in vitro studies have isolated oligodendrocyte progenitor cells from adult rat CNS. These cells can be identified by A2B5 antibodies and, in appropriate in vitro environments, can give rise to oligodendrocytes (Ffrench-Constant and Raff, 1986; Wolswijk and Noble, 1989; Shi et al., 1998). These cells also express the platelet-derived growth factor- $\alpha$ receptor $(\operatorname{PDGF} \alpha \mathrm{R})$ and the in-

Received Dec. 6, 1999; revised June 9, 2000; accepted June 12, 2000.

This research was supported by National Institutes of Health Grants NS35058 and NS38667 (both to B.D.T.). We thank Dr. Susan Staugaitis for helpful comments, Vikki Pickett for typing and editing this manuscript, and the National Neurological Research Specimen Bank, VAMC Wadsworth Division (Los Angeles, CA 90073), for fixed tissue.

Correspondence should be addressed to Dr. Bruce D. Trapp, Department of Neurosciences/NC30, Lerner Research Institute, Cleveland Clinic Foundation, 9500 Euclid Avenue, Cleveland, OH 44195. E-mail: trappb@ccf.org.

Copyright (C) 2000 Society for Neuroscience $0270-6474 / 00 / 206404-09 \$ 15.00 / 0$ tegral membrane proteoglycan NG2 (Nishiyama et al., 1999). NG2 and $\mathrm{PDGF} \alpha \mathrm{R}$ are detected on oligodendrocyte progenitor cells, but not on oligodendrocytes, both in vitro (Stallcup and Beasley, 1987; Richardson et al., 1988; Nishiyama et al., 1996a) and in developing rodent brain (Pringle and Richardson, 1993; Nishiyama et al., 1996b; Trapp et al., 1997). NG2-positive, PDGF $\alpha$ R-positive cells remain abundant throughout the adult rodent CNS (Levine et al., 1993; Nishiyama et al., 1996b; Reynolds and Hardy, 1997) and have the potential to generate oligodendrocytes.

Cells with phenotypic markers of rodent oligodendrocyte progenitors also have been detected in adult human brain (Armstrong et al., 1992; Gogate et al., 1994; Scolding et al., 1998) and MS lesions (Scolding et al., 1998; Wolswijk, 1998). To date, however, cells with the density and complex morphology of rodent NG2positive, PDGF $\alpha$ R-positive cells have not been described in human brains. The present study identifies a population of NG2-positive cells in adult human brain that appears identical to that in rodent brain. In chronic MS lesions, NG2-positive cells were reduced in number and often were elongated; some expressed p $75^{\mathrm{NTR}}$.

\section{MATERIALS AND METHODS}

Tissue. Twelve MS brains, two brains from individuals without neurological disease, and four brains from individuals with other neurological diseases (OND) were investigated in this study. The ages of MS patients (seven females and five males) at the time of death ranged from 18 to 69 years. Salient features of each patient and the lesions analyzed are listed in Table 1. Demyelinated lesions were characterized as active, chronic active, or chronic inactive, as described previously (Bö et al., 1994; Trapp et al., 1998). At autopsy each brain was cut into 1 -cm-thick coronal slabs, immersion-fixed in $4 \%$ paraformaldehyde and $0.08 \mathrm{M}$ Sorenson's buffer for a period ranging from $31 \mathrm{hr}$ to 2 weeks, and then transferred into cryoprotection solution for a minimum of $12 \mathrm{hr}$. Sections $(30 \mu \mathrm{m}$ thick) were cut on a freezing sliding microtome and stored in cryostorage solution in 24 -well culture plates at $-20^{\circ} \mathrm{C}$. Free-floating sections also were cut from frozen blocks that were thawed in $4 \%$ paraformaldehyde.

Immunocytochemistry. Free-floating sections $(30 \mu \mathrm{m}$ thick) removed from cryostorage $\left(-20^{\circ} \mathrm{C}\right)$ were pretreated with microwaving (except for NG2, PDGF $\alpha$ R, and p $\left.75^{\mathrm{NTR}}\right)$ in $10 \mathrm{~mm}$ citrate buffer, pH $6.0(2 \times 5 \mathrm{~min})$, incubated in $3 \% \mathrm{H}_{2} \mathrm{O}_{2} / 10 \%$ Triton $\mathrm{X}-100 / \mathrm{PBS}$ for $30 \mathrm{~min}(0.3 \%$ Triton $\mathrm{X}-100$ was used for NG2), and immunostained by the avidin-biotin com- 
Table 1. Clinical and MS lesion data of patients included in NG2 and p75 studies

\begin{tabular}{|c|c|c|c|c|c|c|c|}
\hline \multirow[b]{2}{*}{$\begin{array}{l}\text { Patients and disease } \\
\text { category }\end{array}$} & \multirow[b]{2}{*}{$\begin{array}{l}\text { Age/ } \\
\text { gender }\end{array}$} & \multirow[b]{2}{*}{$\begin{array}{l}\text { Disease } \\
\text { duration }\end{array}$} & \multirow[b]{2}{*}{ Autolysis } & \multirow{2}{*}{$\begin{array}{l}\text { Lesion } \\
\text { number } \\
\text { analyzed }\end{array}$} & \multicolumn{3}{|c|}{ Lesion activity } \\
\hline & & & & & Active & $\begin{array}{l}\text { Chronic } \\
\text { active }\end{array}$ & $\begin{array}{l}\text { Chronic } \\
\text { inactive }\end{array}$ \\
\hline MS-1 SP & $53 / \mathrm{M}$ & 22 years & $5 \mathrm{hr}$ & 18 & 0 & 2 & 16 \\
\hline MS-2 SP & $69 / \mathrm{F}$ & 46 years & $4.5 \mathrm{hr}$ & 4 & 0 & 0 & 4 \\
\hline MS-3 RR & $43 / \mathrm{M}$ & 9 months & $3 \mathrm{hr}$ & 1 & 1 & 0 & 0 \\
\hline MS-4 SP & 43/M & 9 years & $7 \mathrm{hr}$ & 3 & 0 & 1 & 2 \\
\hline MS-5 PP & $32 / \mathrm{M}$ & 10 months & $14 \mathrm{hr}$ & 1 & 1 & 0 & 0 \\
\hline MS-6 PP & $18 / \mathrm{F}$ & 2 weeks & $<24 \mathrm{hr}$ & 10 & 4 & 6 & 0 \\
\hline MS-7 SP & $56 / \mathrm{F}$ & 26 years & $48 \mathrm{hr}$ & 1 & 1 & 0 & 0 \\
\hline MS-8 PP & $35 / \mathrm{F}$ & 2 weeks & $<24 \mathrm{hr}$ & 4 & 0 & 4 & 0 \\
\hline MS-9 PP & $29 / \mathrm{F}$ & 5 years & $<24 \mathrm{hr}$ & 1 & 0 & 1 & 0 \\
\hline MS-10 RR & $48 / \mathrm{F}$ & 18 years & $35 \mathrm{hr}$ & 3 & 0 & 2 & 1 \\
\hline MS-11 PP & $36 / \mathrm{M}$ & 4 years & $<24 \mathrm{hr}$ & 2 & 2 & 0 & 0 \\
\hline MS-12 SP & $49 / \mathrm{F}$ & 7 years & $6 \mathrm{hr}$ & 7 & 4 & 3 & 0 \\
\hline Total & & & & 55 & 13 & 19 & 23 \\
\hline \multicolumn{8}{|l|}{ Normal controls } \\
\hline Cardiac arrest & $52 / \mathrm{M}$ & & $16 \mathrm{hr}$ & & & & \\
\hline Cardiac arrest & $91 / \mathrm{F}$ & & $9 \mathrm{hr}$ & & & & \\
\hline \multicolumn{8}{|l|}{ OND* } \\
\hline SSPE & $8 / \mathrm{M}$ & 2 years & $20 \mathrm{hr}$ & & & & \\
\hline Epilepsy & $27 / F$ & & $18 \mathrm{hr}$ & & & & \\
\hline Devic's & $70 / \mathrm{F}$ & & $6 \mathrm{hr}$ & & & & \\
\hline Primary CNS & $54 / \mathrm{M}$ & 2 years & $6 \mathrm{hr}$ & & & & \\
\hline Lymphoma & & & & & & & \\
\hline
\end{tabular}

SP, Secondary progressive, RR, relapsing/remitting, PP, primary progressive, ${ }^{*}$ other neurological diseases.

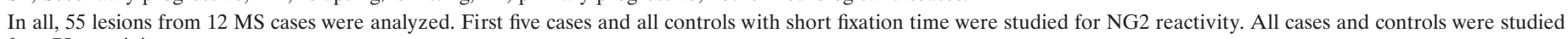
for p75 reactivity.

plex procedure with DAB, as described previously (Trapp et al., 1998). Sections that were double-labeled for immunofluorescence staining were pretreated as above, incubated with two primary antibodies for 1-7 d at $4^{\circ} \mathrm{C}$ and with fluorescein- and Texas Red-conjugated secondary antibodies for $1 \mathrm{hr}$ or biotinylated secondary antibody ( $1 \mathrm{hr}$ ), followed by fluorophoreconjugated avidin D (1 hr). All sections labeled with NG2 antibodies were not microwaved and were pretreated with $0.3 \%$ Triton X-100.

For NG2 staining the Tyramide Signal Amplification (TSA; NEN Life Science Products, Boston, MA) method was used by following the manufacturer's instructions. The TSA-Indirect kit was used for DAB immunocytochemistry and the TSA-Direct kit for immunofluorescence staining (NEN Life Science Products).

TUNEL and $p 75^{\mathrm{NTR}}$ staining. Three active lesions, nine chronic active lesions, and four chronic inactive lesions from eight MS brains were dual-labeled for p75 NTR and DNA fragmentation. TUNEL was performed by in situ end labeling (ISEL ${ }^{+}$) (Blaschke et al., 1996) on free-floating MS sections with minor modifications. Sections $(25 \mu \mathrm{m}$ thick) were washed with PBS $(2 \times 5 \mathrm{~min})$ and $2 \times \operatorname{SSPE}(1 \times 5 \mathrm{~min})$ and then were permeabilized in $10 \%$ Triton X-100/2 $\times$ SSPE for $30 \mathrm{~min}$. Sections were equilibrated in reaction buffer (100 mM Na-cacodylate, $2 \mathrm{mM} \mathrm{CoCl}_{2}, 0.25 \mathrm{mg} / \mathrm{ml}$ of BSA, and $30 \mathrm{~mm}$ Trizma base, pH7.2; Sigma, St. Louis, MO) for $1 \mathrm{~min}$ and then for $60 \mathrm{~min}$ in labeling mixture $(1 \mu \mathrm{l}$ of reaction buffer contains $0.04 \mathrm{nmol}$ of digoxigenin-11-dUTP, $0.4 \mathrm{nmol}$ of dATP, and $0.3 \mathrm{U}$ of terminal deoxynucleotidyl transferase; Boehringer Mannheim, Indianapolis, IN) at $37^{\circ} \mathrm{C}$ in a humidifying chamber. The reaction was terminated by incubating the sections in $2 \times \mathrm{SSPE}$ at $65^{\circ} \mathrm{C}$ for $1 \mathrm{hr}$. Slides were placed in $1 \times$ TBS $(50 \mathrm{~mm}$ Tris- $\mathrm{HCl})$ three times for $10 \mathrm{~min}$ each, $1 \%$ blocking reagent (Boehringer Mannheim) in TBS/0.3\% Triton X-100 for $1 \mathrm{hr}$, and alkaline phosphatase-conjugated anti-digoxygenin Fab fragments (Boehringer Mannheim) at a dilution of 1:500 in blocking solution for $16 \mathrm{hr}$. Slides were washed three times in $1 \times$ TBS. Alkaline phosphatase activity was detected by enzymatic reaction by using nitroblue tetrazolium (NBT; Boehringer Mannheim) and 5-bromo-4-chloro-3-indolyl phosphate (BCIP; Boehringer Mannheim) as substrates to produce a blue precipitate. Then the sections were double-labeled with p75 ${ }^{\text {NTR }}$ antibodies by the avidinbiotin procedure as described above.

Antibodies. Sections were immunostained with the following antibodies: 9.2.27 mouse anti-human NG2 (a gift from Dr. R. Reisfeld, Department of Immunology, The Scripps Research Institute, La Jolla, CA; PharMingen, San Diego, CA), rabbit anti-NG2 (a gift from Dr. W. Stallcup, The Burnham Institute, La Jolla, CA), affinity-purified rabbit anti-human PDGF $\alpha$ R (prepared by Dr. Nishiyama), rat monoclonal PLP (Agmed, Bedford, MA), mouse anti-myelin basic protein (SMI94) and mouse anti- neurofilament (Sternberger Monoclonals, Baltimore, MD), rabbit antihuman p75 NTR (Promega, Madison, WI), mouse anti-leukocyte common antigen (LCA; CD45), mouse anti-MHC class II and rabbit anti-glial fibrillary acidic protein (GFAP; Dako, Glostrup, Denmark), and rabbit anti $\mathrm{P}_{0}$ protein (Trapp et al., 1979).

Confocal microscopy. Confocal imaging was performed on a Leica Aristoplan laser scanning microscope (Leitz Wetzlar, Heidelberg, Germany). Individual confocal optical sections represented $0.5 \mu \mathrm{m}$ axial resolution. The images presented are stacks of 12-38 optical sections; they were collected individually in the green and red channels to eliminate "bleedthrough" and were merged thereafter.

\section{RESULTS}

Based on the abundance of NG2-, PDGF $\alpha$ R-positive cells in adult rodent brain, it is very likely that a similar cell population is present in adult human brain. However, to date, stellate-shaped NG2- or PDGF $\alpha$ R-positive cells have not been identified in tissue sections from adult human brain. Therefore, the effects of a variety of fixation and pretreatment protocols were tested for the efficacy of $\mathrm{NG} 2$ and $\mathrm{PDGF} \alpha \mathrm{R}$ staining in brain sections from normal adult human brain. NG2-positive cells were detected in adult human brain if the tissue was fixed for $<48 \mathrm{hr}$ in $4 \%$ paraformaldehyde, minimally treated with Triton X-100 (0.3\%), and not microwaved. The distribution, shape, and relationship between NG2-positive cells in sections from adult human brain (Fig. $1 A$ ) are identical to those described in adult rodent brain (Nishiyama et al., 1996b, 1999). NG2-positive cells and their processes have a lattice-like appearance that covers most of the CNS parenchyma. Many NG2positive cell processes appear to contact processes from other NG2 cells or end on or near blood vessels. In sections from normalappearing regions of other neurologically diseased brains, NG2 antibodies stained stellate-shaped cells and blood vessels as in normal control brains. However, NG2-positive cells were not detected in white or gray matter regions infiltrated by B-cells in the lymphoma brain or in demyelinated and macrophage-infiltrated 


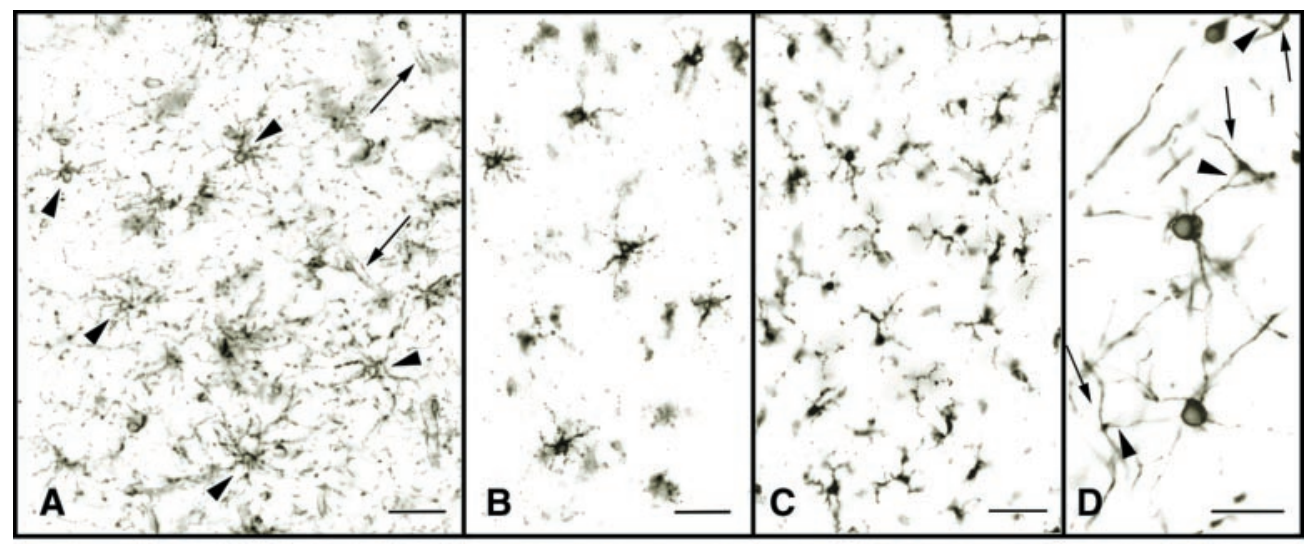

Figure 1. NG2 cells are abundant in the adult human brain and are distinct from microglia, oligodendrocytes, and astrocytes. NG2 antibodies stain relatively small perikarya, which emanate stellateshaped processes that occupy discrete domains $(A$, arrowheads $)$. NG2 is detected on endothelial cells also ( $A$, arrows). PDGF $\alpha \mathrm{R}$ antibodies stain cells with distributions identical to those of NG2 cells $(B)$. PDGF $\alpha \mathrm{R}$ is enriched in the cell bodies and in the larger processes. NG2 and PDGF $\alpha$ R cell morphology differs from MHC class II-stained microglia $(C)$, which have shorter, thicker, and more irregularly shaped processes and from PLPpositive oligodendrocytes, which send processes $(D$, arrowheads $)$ to myelin internodes $(D$, arrows $)$. In double-labeled confocal images NG2 $(E, F$, red $)$ LCA $(E$, green $)$, and GFAP $(F$, green $)$ antibodies stain different cell populations. Scale bars: $A-C, 50 \mu \mathrm{m} ; D-F, 30 \mu \mathrm{m}$.
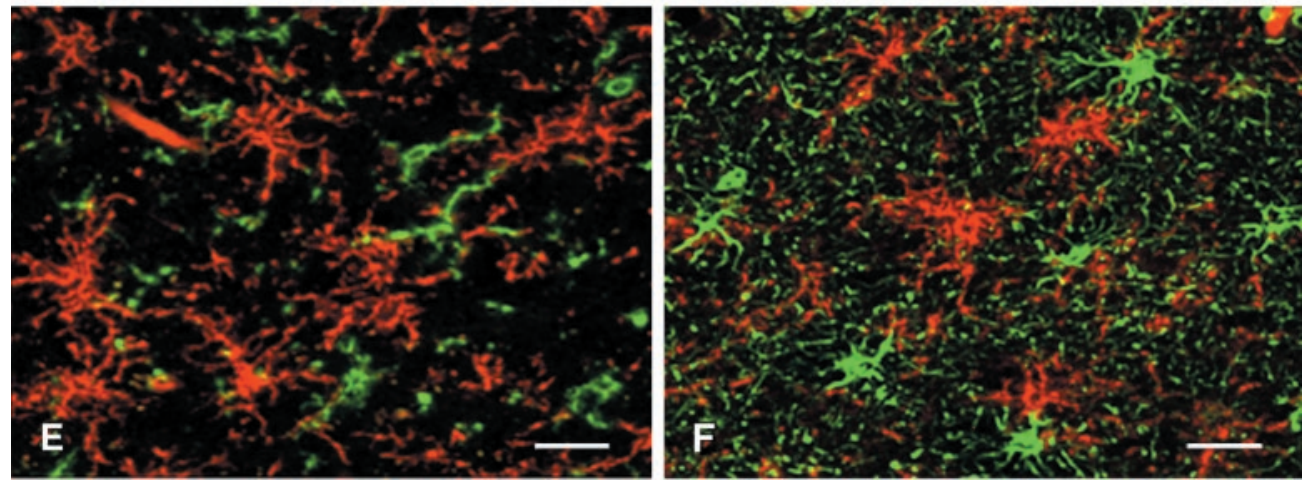

areas of the subacute sclerosing parencephalitis (SSPE) brain (data not shown).

Obstacles also hindered the detection of PDGF $\alpha$ R immunoreactivity in normal human brain. Various fixation, pretreatment protocols and numerous PDGF $\alpha$ R antibodies were tested without satisfactory results. To date, we have detected PDGF $\alpha$ R immunoreactivity successfully in some sections fixed in $4 \%$ paraformaldehyde for short periods of time $(<48 \mathrm{hr})$ and treated with $10 \%$ Triton X-100 (Fig. 1B), using an affinity-purified PDGF $\alpha$ R antibody directed against the $\mathrm{C}$-terminal of human PDGF $\alpha \mathrm{R}$. When this PDGF $\alpha \mathrm{R}$ antibody works, it stains a population of cells with a distribution identical to NG2 cells. The cells, however, have a slightly different morphology, because $\mathrm{PDGF} \alpha \mathrm{R}$ is enriched in cell bodies and the larger processes and is not detected on the thinner, highly ramified processes. This difference between $\mathrm{PDGF} \alpha \mathrm{R}$ and NG2 distribution on the same cell has been documented in adult rodent brain (Nishiyama et al., 1996b). Because NG2 antibodies worked more consistently than $\mathrm{PDGF} \alpha \mathrm{R}$ antibodies, the remainder of our studies used NG2 to characterize this unique cell population further in normal and MS brain.

To confirm that NG2-positive cells are distinct from other glial cells in normal human brain, we stained sections with antibodies specific for oligodendrocytes, microglia, and astrocytes. MHC class II antibodies, a marker for activated microglia cells, also labeled a population of process-bearing cells (Fig. 1C). Microglia processes were thicker and shorter, and they extended from the perikarya in a more asymmetrical manner than did the processes of NG2 cells (Fig. 1A). Oligodendrocyte perikarya identified by proteolipid protein (PLP) (Fig. 1D) extended fewer processes than NG2 cells, and some of these processes could be traced to myelin internodes. PLP antibodies did not stain NG2 cells. The discordance of NG2 and microglia staining was demonstrated by dual labeling the sections with NG2 (Fig. $1 E$, red) and LCA (Fig. $1 E$, green), a marker for resting and activated microglia, monocytes, macrophages, and lymphocytes. When these sections were examined by confocal microscopy, two distinct cell populations were identified. A similar comparison was performed with NG2 (Fig. $1 F$, red) and GFAP antibodies (Fig. $1 F$, green), a marker for astrocytes. GFAP antibodies stained a population of stellate-shaped cells that often extended processes to blood vessels. Endothelial cells also expressed NG2, and in merged confocal images many vessels appear yellow because of the close apposition of astrocyte endfeet and endothelial cell surface membranes. Perikarya of astrocytes were NG2-negative, and perikarya of NG2 cells were GFAP-negative.

\section{Detection of NG2 cells in MS lesions}

NG2-positive cells were detected in all MS lesions that were fixed appropriately. Their distribution and shape varied from lesion to lesion (Fig. 2A-D). Based on shape, two types of NG2-positive cells were identified: stellate (Fig. $2 E$ ) and elongated (Fig. $2 F$ ). Figure $2 A-D$ schematically depicts the distribution of stellate and elongated NG2-positive cells in four MS lesions. These lesions are displayed schematically because they reflect common NG2 distributions in the 27 lesions that were analyzed. In addition, Figure $2 A-D$ visually summarizes NG2-positive distribution in lesions that are often several centimeters in size. Stellate NG2-positive cells were detected in the subependymal layer of MS lesions, all gray matter lesions, and in some white matter parenchymal lesions. Elongated NG2-positive cells extended single, bipolar, or multiple processes, and they often formed networks that appeared to be interconnected. Groups of elongated NG2-positive cells were detected at the border of some MS lesions, around vessels, surrounding myelinated regions within lesions, or as isolated islands within the lesions. Elongated cells most often were oriented parallel to axons within the lesions.

Because the elongated shape of some NG2 cells in MS lesions resembled that of activated microglia/monocytes, sections were immunostained with NG2 (Fig. 2G, red) and LCA (Fig. 2G, green) antibodies and examined by confocal microscopy. Although both antibodies stained elongated cells, there was no overlap in the distribution of NG2 and LCA. A similar comparison of the distribution of NG2 (Fig. $2 H$, red) and GFAP (Fig. $2 H$, green) in MS lesions was performed. As described above, in normal-appearing white matter NG2 and GFAP antibodies stained different cell populations. These studies establish that NG2-positive cells in MS lesions are distinct from microglia, monocytes, lymphocytes, macrophages, and astrocytes.

The distribution and shape of NG2-positive cells in MS lesions 

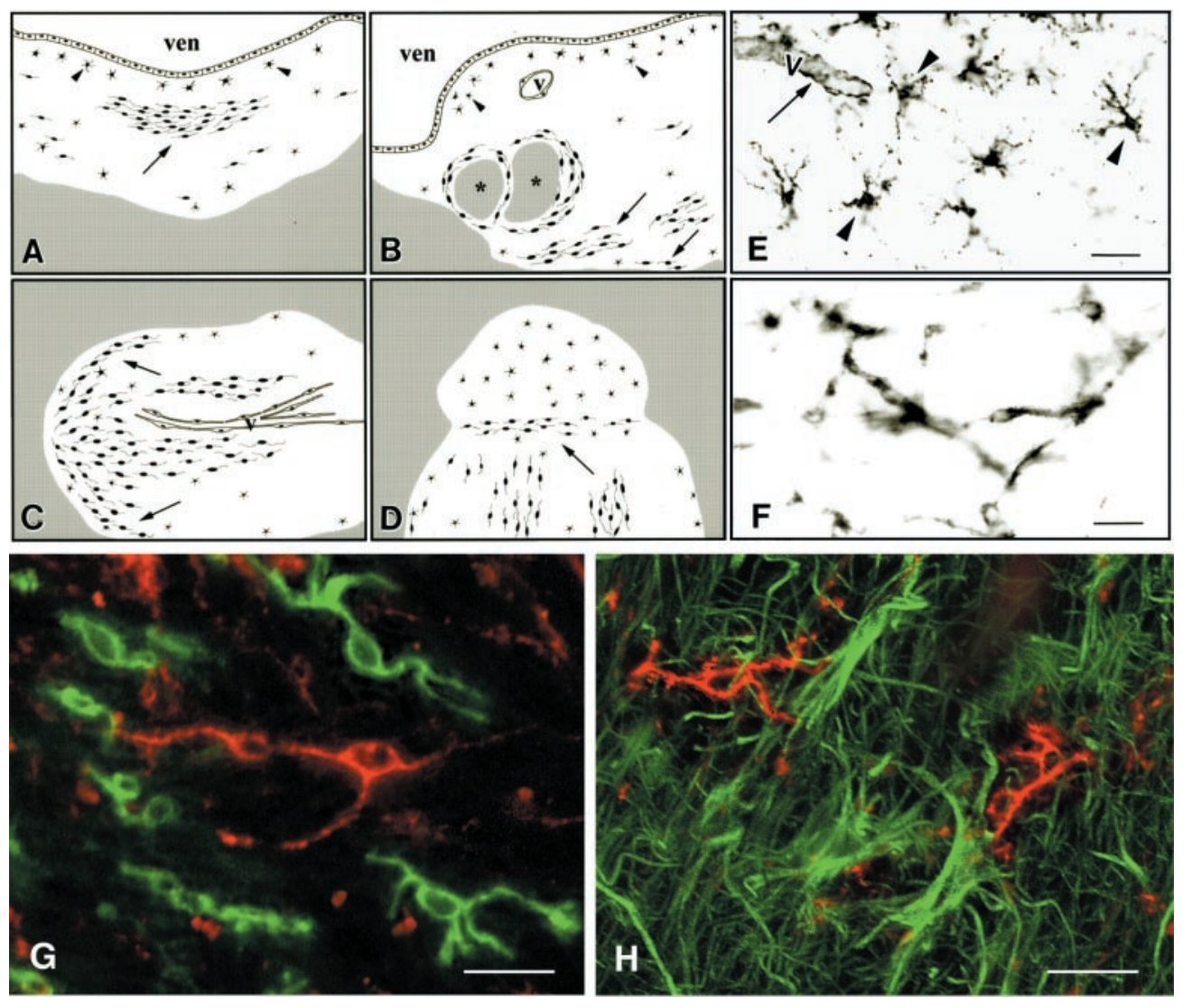

Figure 2. NG2 cells are detected in MS lesions and are distinct from microglia/ monocytes and astrocytes. $A-D$, Artistic renditions of the distribution of NG2 cells in four MS lesions. The white areas are demyelinated periventricular $(A, B)$ or subcortical $(C, D)$ white matter, and the gray areas are myelinated white matter. NG2 cells (black cells) are distributed unevenly in the MS lesions $(A-D)$. They have stellate (arrowheads) or elongated (arrows) shapes. ven, Ventricle; $V$, vessels; $*$, myelinated areas within a periventricular lesion. $E, F, \mathrm{NG} 2$-stained sections of MS lesions that contain stellate $(E$, arrowheads) or elongated $(F)$ cells. Endothelial cells $(E$, arrow) are stained by NG2 antibodies also. Confocal images of MS lesions that have been double-labeled with NG2 $(G, H$, red $)$, and the leukocyte/microglia marker LCA $(G$, green) or the astrocyte marker GFAP (H, green) have established that NG2 cells are distinct from leukocytes/microglia and astrocytes in MS lesions. MS case 1. Scale bars: $E, 50 \mu \mathrm{m}$; $F, 30 \mu \mathrm{m} ; G, H, 20 \mu \mathrm{m}$.
Table 2. Lesions containing stellate or elongated $\mathrm{NG2}^{+}$cells

\begin{tabular}{|c|c|c|c|c|c|c|}
\hline \multirow[b]{3}{*}{$\mathrm{NG}^{+}$cells } & \multicolumn{6}{|c|}{ Lesion category } \\
\hline & \multicolumn{2}{|c|}{ Active } & \multicolumn{2}{|c|}{ Chronic active } & \multicolumn{2}{|c|}{ Chronic inactive } \\
\hline & Edge & Core & Edge & Core & Edge & Core \\
\hline Stellate & $1 / 2$ & $0 / 2$ & $2 / 3$ & $0 / 3$ & $22 / 22$ & $22 / 22$ \\
\hline Elongated & $1 / 2$ & $0 / 2$ & $2 / 3$ & $0 / 3$ & $18 / 22$ & $18 / 22$ \\
\hline
\end{tabular}

were correlated with the stage of inflammation and demyelinating activity (Table 2 ). Two active, three chronic active, and 22 chronic inactive white matter lesions and three gray matter lesions were analyzed. Stellate and elongated NG2-positive cells were not detected in the three chronic active or two active MS lesions except on the edges of active lesions. In contrast, stellate NG2-positive cells were detected in 22 of 22 chronic inactive lesions, while elongated NG2 cells were detected in 18 of 22 chronic inactive lesions. The four chronic inactive lesions that did not contain elongated NG2-positive cells contained widely and evenly distributed stellate cells (Fig. 3A). The density of stellate NG2-positive cells was determined in three chronic inactive white matter lesions and was compared with the density of NG2-positive cells in surrounding normal-appearing white matter (Fig. 3B). Normalappearing white matter contained between 140 and 150 NG2 cells/ $\mathrm{mm}^{2}$ of tissue ( $30 \mu \mathrm{m}$ thick). In contrast, the three lesion areas contained 80,40 , and 70 stellate $\mathrm{NG} 2$ cells $/ \mathrm{mm}^{2}$ of tissue. This decrease in NG2 cell density was statistically significant $(p<$ 0.001).

The distribution of NG2 cells also was analyzed in demyelinated regions of cerebral cortex. Figure $4 A$ shows the distribution of myelin basic protein in a section that contains normally myelinated subcortical white matter and demyelinated cortex with occasional patches of remyelination. In a section cut adjacent to the myelin basic protein (MBP)-stained section, the appearance and overall distribution of NG2-positive cells (Fig. 4B,C) in demyelinated cortical MS lesions were similar to those found in myelinated cortex. NG2-positive cells extended multiple processes that formed a lattice-like network. Similar NG2-positive cell distribution was detected in all three cortical lesions that were analyzed.

\section{Subpopulations of elongated NG2 cells express p $75^{\text {NTR }}$}

The $\mathrm{p} 75^{\mathrm{NTR}}$ neurotrophin receptor is a member of the tumor necrosis factor receptor family and has been implicated in signaling oligodendrocyte survival or death (Casaccia-Bonnefil et al., 1996; Ladiwala et al., 1998; Yoon et al., 1998). To investigate the potential role of $\mathrm{p} 75^{\mathrm{NTR}}$ in oligodendrocyte lineage cells in MS lesions, we stained serial sections with MBP, NG2, and p $75^{\text {NTR }}$ antibodies. The distribution of myelin basic protein delineates a periventricular MS lesion (Fig. 5A). The lesion contains three myelinated regions (Fig. $5 A$, asterisks). In the adjacent section (Fig. $5 B$ ) most of the NG2-positive cells within the demyelinated areas were elongated, with the exception of stellate-shaped NG2 cells in the subependymal layer (Fig. $5 B$, arrowheads). Figure $5 C$ shows the distribution of $\mathrm{p} 75^{\mathrm{NTR}}$ in an additional serial section of the same lesion. p75 ${ }^{\mathrm{NTR}}$ immunoreactivity was detected in elongated cells (Fig. $5 D$ ) that have a distribution similar to that of the elongated NG2-positive cells. In contrast, p $75^{\mathrm{NTR}}$ was not detected in stellate-shaped cells located in the subependymal layer nor in normal-appearing white matter. $\mathrm{p} 75^{\mathrm{NTR}}$ antibodies also stained small round cells outside this lesion (Fig. 5E, arrowheads). Dual labeling identified many of these cells as oligodendrocytes (data not shown).

To confirm that $\mathrm{p} 75^{\mathrm{NTR}}$ antibody labeled NG2-positive cells, we double-labeled sections with $\mathrm{p} 75^{\mathrm{NTR}}$ and NG2 antibodies and examined them by confocal microscopy. Many elongated NG2positive cells expressed p75 NTR (Fig. 6A,B, yellow). However, not all elongated NG2-positive cells expressed detectable levels of p $75^{\text {NTR }}$ (Fig. 6A,B, arrowheads), and not all elongated p75 ${ }^{\text {NTR }}$ cells expressed detectable levels of NG2 (Fig. 6A, arrows). Stellate-shaped NG2-positive cells in the subependymal layer of 

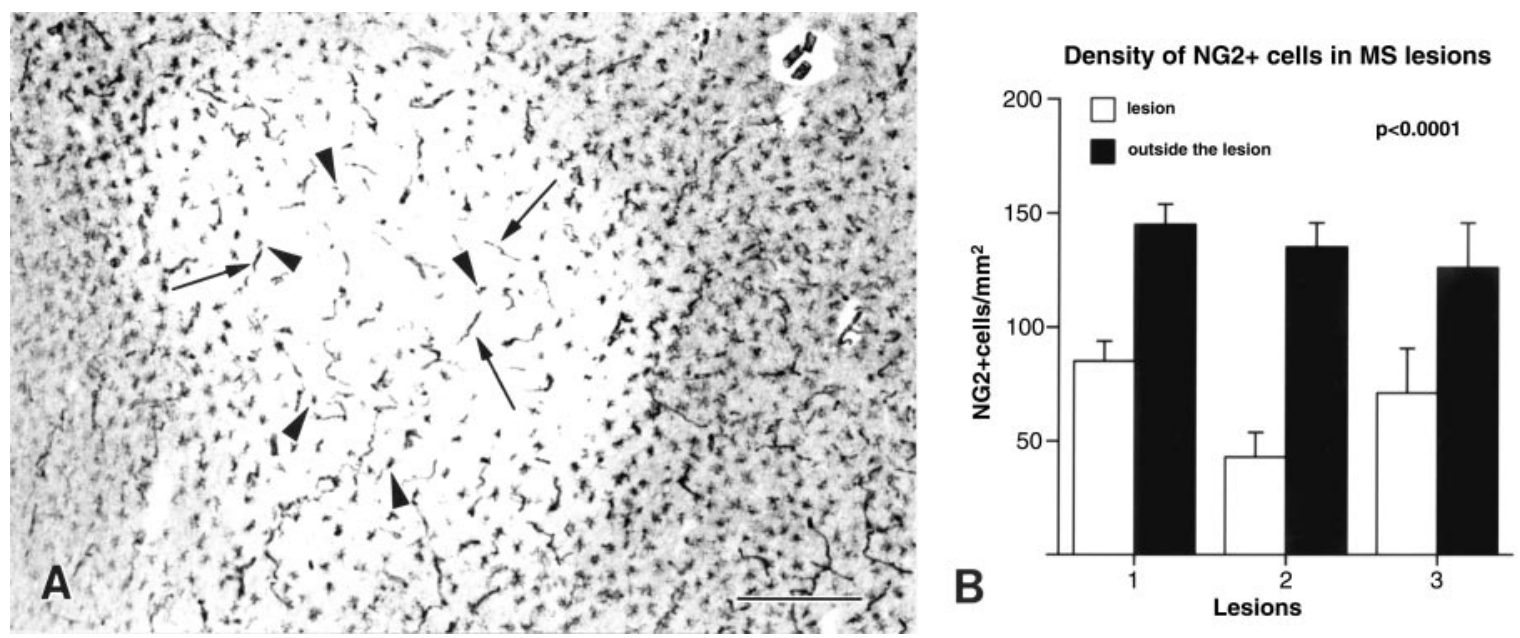

Figure 3. Some white matter MS lesions contain predominately stellate-shaped NG2 cells. The lighter area in $A$ demarcates a white matter MS lesion as identified by myelin staining in an adjacent section. Stellate-shaped NG2 cells (arrowheads) are present within the lesion. Blood vessels (arrows) are labeled also. In three separate MS lesions that contained predominately stellate-shaped NG2 cells, NG2 cell density within the lesion has been reduced significantly $(p<0.0001)$ when compared with NG2 cell density outside the lesion $(B)$. MS case 2. Scale bar in $A, 400 \mu \mathrm{m}$.

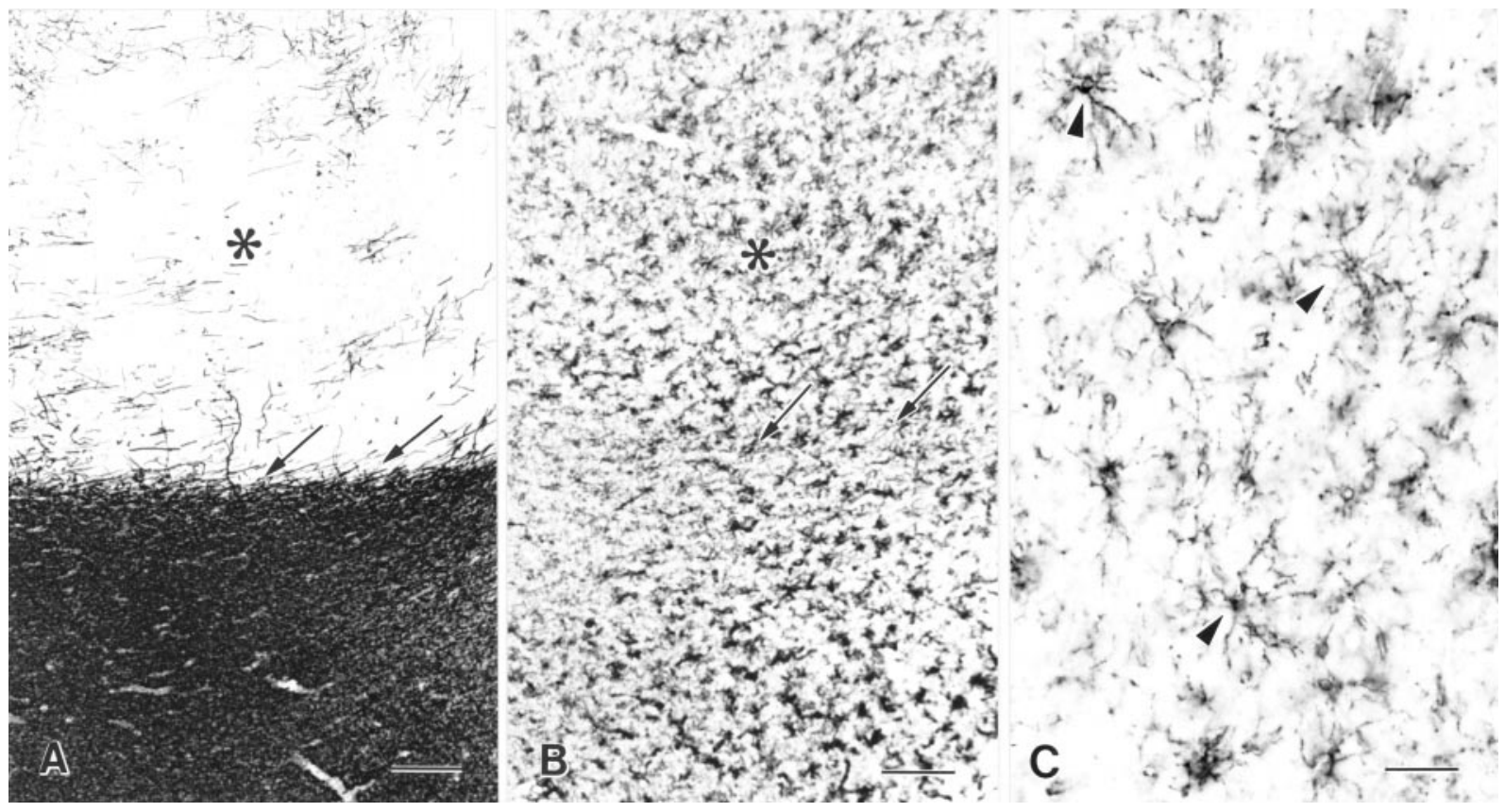

Figure 4. NG2 cell distribution appears unchanged in gray matter MS lesions. The distributions of myelin basic protein $(A)$ and NG2 $(B, C)$ are compared in adjacently cut sections from the cerebral cortex of an MS brain. The cerebral cortex $\left({ }^{*}\right.$, white area in $\left.A\right)$ is demyelinated with some remyelination. Subcortical white matter (black area in $A$ ) appears normally myelinated. The distribution and apparent density of NG2 cells $(B)$ are not altered in demyelinated gray matter. The shape of NG2 cells in demyelinated gray matter ( $C$, arrowheads) appears relatively normal. Arrows in $A$ and $B$ demarcate the gray matter-white matter border. MS case 2. Scale bars: $A, B, 200 \mu \mathrm{m} ; C, 50 \mu \mathrm{m}$.

MS lesions were $\mathrm{p} 75^{\mathrm{NTR}}$-negative in these double-labeling studies (Fig. 6C, arrow).

To investigate whether $\mathrm{p} 75^{\mathrm{NTR}}$-positive cells in MS lesions were distinct from neurons, other glial cells, and leukocytes, we doublelabeled sections with $\mathrm{p} 75^{\mathrm{NTR}}$ and phenotypic markers for these various cell types. p $75^{\mathrm{NTR}}$ did not colocalize with the microglia, monocytes, lymphocyte marker LCA (Fig. 6D), or with GFAP or $\mathrm{P}_{0}$ protein (data not shown). $\mathrm{p} 75^{\mathrm{NTR}}$ colocalized with neurofilament protein in the rare subcortical neuron and in appropriate p $75^{\text {NTR }}$-positive cortical neurons and their axons (data not shown). In white matter lesions the elongated $\mathrm{p} 75^{\mathrm{NTR}}$ cells were neurofilament-negative and were oriented parallel to neurofilament-positive axons (Fig. 6E, arrows). These studies establish that the p $75^{\mathrm{NTR}^{\mathrm{T}}}$-positive elongated cells present in MS lesions are distinct from neurons, astrocytes, leukocytes, or Schwann cells.
Elongated p $75^{\mathrm{NTR}}$-positive cells were present in most of the active, chronic active, and chronic inactive lesions that were analyzed (Table 3). Unlike NG2, p75 ${ }^{\text {NTR }}$ immunostaining withstands long fixation. In addition to all of the lesions that were studied for NG2, an additional 11 active, 16 chronic active, and one chronic inactive lesions were stained for $\mathrm{p} 75^{\mathrm{NTR}}$. $\mathrm{p} 75^{\mathrm{NTR}}$-positive elongated cells were present and appeared healthy in acute MS lesions that contained myelin protein-positive debris within macrophages and/or the neuropil (Fig. $6 F$ ). Elongated p $75^{\text {NTR }}$-positive cells (Fig. 6G, green) often were found at the edge of active MS lesions, extending short distances within the normal-appearing white matter (Fig. 6G, red).

\section{p75 ${ }^{\text {NTR }}$-positive cells are not TUNEL-positive}

To investigate whether $\mathrm{p} 75^{\mathrm{NTR}}$-positive cells are dying by apoptosis, we dual-processed sections from three active, nine chronic 


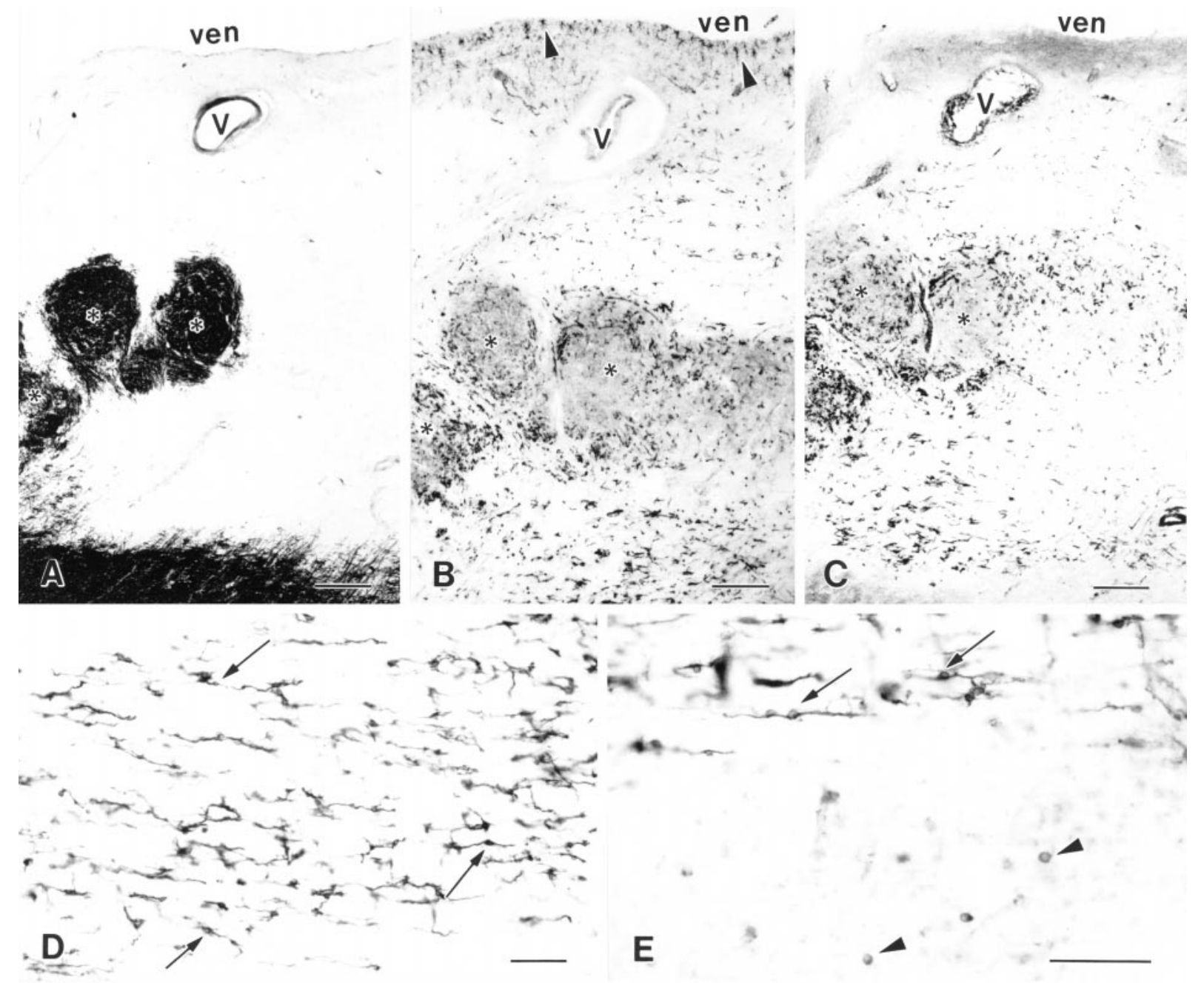

Figure 5. Elongated NG2 and p75 ${ }^{\mathrm{NTR}}$-positive cells have similar distributions in MS lesions. Three serial sections are stained with MBP $(A)$, NG2 $(B)$, and $75^{\mathrm{NTR}}(C)$ antibodies. White areas in $A$ represent demyelinated periventricular white matter. Elongated NG2 cells $(B)$ and elongated p75 $5^{\mathrm{NTR}}$ positive cells $(C)$ have similar distributions within the MS lesion. NG2 antibodies ( $B$, arrowheads), but not $\mathrm{p} 75^{\mathrm{NTR}}$ antibodies $(C)$, have stained a population of stellate-shaped cells located subependymally. $V$, Vessel; ven, ventricle; *, myelinated fibers within the lesion. Most p75 ${ }^{\mathrm{NTR}}-$ positive cells are elongated within the lesion $\left(D\right.$, arrows) and at the edge of the lesion $\left(E\right.$, arrows). However, small round p $75^{\mathrm{NTR}}$-positive cells also have been detected in normal-appearing white matter adjacent to MS lesions ( $E$, arrowheads). MS case 1 . Scale bars: $A-C, 500 \mu \mathrm{m} ; D, E, 100 \mu \mathrm{m}$.

active, and four chronic inactive lesions for $\mathrm{p} 75^{\mathrm{NTR}}$ immunoreactivity and apoptotic cell death as determined by TUNEL. In all of the active and chronic active lesions, both p $75^{\mathrm{NTR}}$ - and TUNELpositive cells were detected (Fig. $6 H$ ). Most TUNEL-positive cells were located within the lesions; some were located in perivascular cuffs, whereas others were located in the CNS parenchyma. With one possible exception, p75 ${ }^{\mathrm{NTR}}$-positive cells were not TUNELpositive. Many TUNEL-positive cells had the morphology of lymphocytes, macrophages, and/or dead cells inside macrophages. Most p $75^{\text {NTR }}$-positive cells had bipolar shapes and healthy appearances (Fig. 6I). The two chronic inactive lesions contained fewer TUNEL-positive cells and no colocalization between TUNEL and p75 ${ }^{\text {NTR }}$.

\section{DISCUSSION}

Most neuroscience textbooks describe four major neuroglial cell populations in the human CNS: ependymal cells, astrocytes, oligodendrocytes, and microglia. This report describes a fifth glial cell population, identified by the expression of the proteoglycan NG2, which appears as abundant but distinct from astrocytes, oligodendrocytes, and microglia. NG2-positive cells also were detected in all of the chronic MS lesions that were analyzed. If these cells retain the ability to produce oligodendrocytes, they represent a target for future remyelination therapies. Similar to astrocytes and microglia, NG2 cells appeared "activated" in MS lesions with altered shape and location. The neurotrophin receptor $\mathrm{p} 75^{\mathrm{NTR}}$ was expressed by some NG2 cells in MS lesions but did not appear to be a limiting event in an obligate apoptotic signaling pathway.

\section{NG2-positive cells are abundant in adult human CNS}

The present report establishes that NG2-positive cell morphology and distribution are similar in adult human and rodent brain. Although NG2-positive cell numbers were not quantified systematically in our analysis, an important concept is that these cells and their processes form a lattice-like network that covers most of the CNS parenchyma. The network-like appearance is more regular in gray than in white matter, indicating that NG2 cell morphology is affected by different CNS environments. The morphology and abundance of NG2 cells raise the possibility that they have functions unrelated to oligodendrocyte production. In rodent brain NG2-positive processes appose nodes of Ranvier (Butt et al., 1999), associate with synapses (Ong and Levine, 1999), and terminate on blood vessels. Collectively, these observations support the possibility that NG2 cells help to maintain CNS homeostasis, including the regulation of neuronal electrical activity.

The detection of putative oligodendrocyte progenitor cells in adult human brain presented a formidable challenge. The 

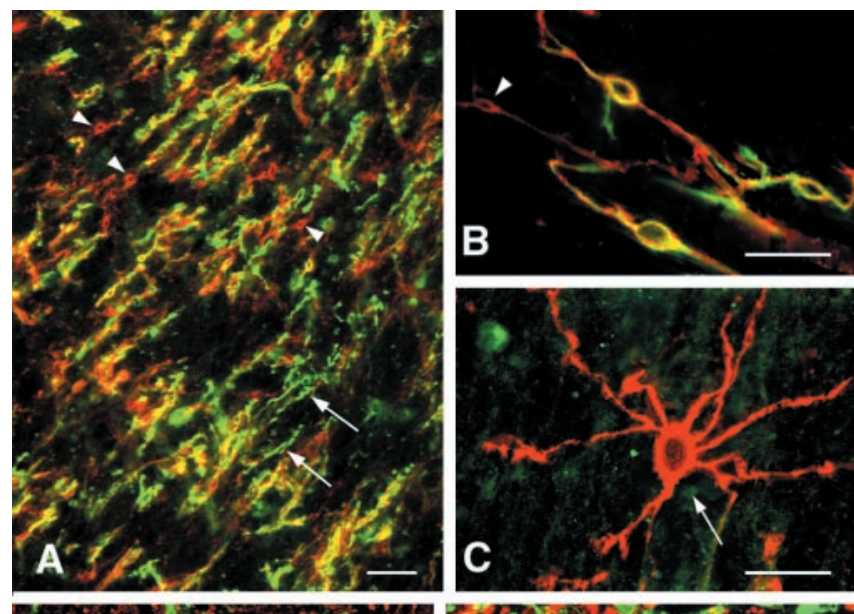

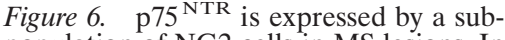
population of NG2 cells in MS lesions. In confocal images that have been doublelabeled with NG2 $(A-C$, red $)$ and p $75^{\mathrm{NTR}}$ ( $A-C$, green) many, but not all, elongated cells express both antigens $(A, B$, yellow). Some elongated p75 NTR' positive cells are NG2-negative (A, green, arrows), and some elongated NG2positive cells are $\mathrm{p} 75^{\mathrm{NTR}}$-negative $(A, B$, red, arrowheads). Stellate-shaped NG2 cells $(C$, red, arrow) are not positive for p $75^{\mathrm{N} T R}$. In confocal images that have been double-labeled with $\mathrm{p} 75^{\mathrm{NTR}}$ and LCA, p $75^{\text {NTR }}$-positive cells ( $D$, green $)$ are distinct from leukocytes, macrophages, or microglia $(D, r e d)$. Based on double labeling for $\mathrm{p} 75^{\mathrm{NTR}}(E$, green $)$ and neurofilaments $(E, r e d)$, elongated $\mathrm{p} 75^{\mathrm{NTR}}$-positive cells usually are oriented parallel to axons $(E$, arrows $)$. p $75^{\mathrm{NTR}^{\mathrm{T}}}$-positive elongated cells $(F$, green $)$ have been detected in MS lesions that contain abundant MBPpositive myelin debris $(F$, red $)$. p $75^{\mathrm{NTR}_{-}}$ positive elongated cells $(G$, green $)$ often are enriched at the edge of MS lesions $(G$, red $=\mathrm{MBP})$. TUNEL-positive cells $(H, I$, blue nuclei) are abundant in MS lesions. However, p $75^{\mathrm{NTR}}$-positive elongated or round cells are rarely TUNEL-positive $(H, I)$. MS case 1 . Scale bars: $A, 50 \mu \mathrm{m}$; $B-G, I, 20 \mu \mathrm{m} ; H, 100 \mu \mathrm{m}$.
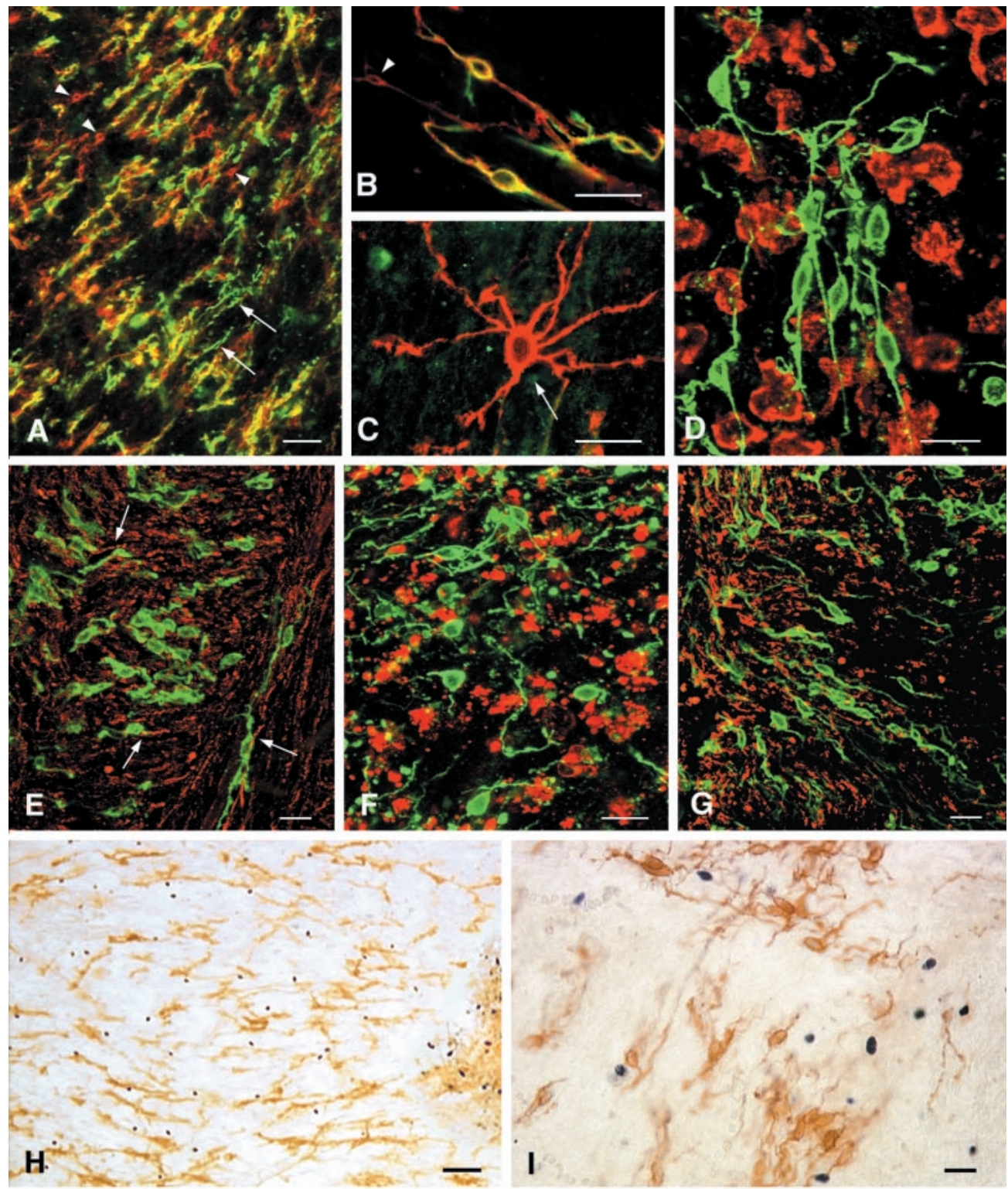

Table 3. Lesions containing elongated or round $\mathrm{p}^{+}$cells

\begin{tabular}{|c|c|c|c|c|c|c|}
\hline \multirow[b]{3}{*}{$\mathrm{p} 75^{+}$cells } & \multicolumn{6}{|c|}{ Lesion category } \\
\hline & \multicolumn{2}{|l|}{ Active } & \multicolumn{2}{|c|}{ Chronic active } & \multicolumn{2}{|c|}{ Chronic inactive } \\
\hline & Inside & Outside & Inside & Outside & Inside & Outside \\
\hline Elongated & $12 / 13$ & $1 / 13$ & $19 / 19$ & $0 / 19$ & $18 / 23$ & $0 / 23$ \\
\hline Round & $12 / 13$ & $7 / 13$ & $19 / 19$ & $10 / 19$ & $20 / 23$ & $21 / 23$ \\
\hline
\end{tabular}

A2B5 ${ }^{+} / \mathrm{GFAP}^{-} / \mathrm{GalC}^{-}$phenotype used in vitro is not reliable because A2B5 is expressed by a variety of cell types in vivo. The use of O4, GFAP, and GalC triple labeling has identified putative progenitors in MS lesions, but not in normal-appearing brain (Wolswijk, 1998). PDGF $\alpha \mathrm{R}$ mRNA and PDGF $\alpha \mathrm{R}$ also were detected in glial cells in normal brain (Gogate et al., 1994) and MS lesions (Scolding et al., 1998). PDGF $\alpha$ R-positive cells, however, had elongated shapes in both control and MS lesions (Scolding et al., 1998). In our analysis the elongated NG2 cells were not detected in normal-appearing adult human brain. As described in adult rodent brain (Nishiyama et al., 1996b), it is possible that $\mathrm{PDGF} \alpha \mathrm{R}$ is enriched in surface membranes of cell bodies and large proximal processes; thus immunostained cells appear elongated because of the lack of detectable staining on thinner processes. In our hands, $\mathrm{PDGF} \alpha \mathrm{R}$ immunocytochemistry has not provided consistent results across multiple tissue samples. When it does work, the labeled cells in normal brain had a distribution identical to that of the stellate-shaped NG2 cells. As described in adult rodent brain (Nishiyama et al., 1996b), $\mathrm{PDGF} \alpha \mathrm{R}$ was enriched in the cell bodies and large processes, but it was not detected on thin ramified processes stained by NG2 antibodies. Based on our results and comparisons to adult rodent brain, it is likely that $\mathrm{PDGF} \alpha \mathrm{R}$ is expressed by all stellate NG2 cells. To date, however, we have not found a pretreatment regimen that permits optimal NG2 and PDGF $\alpha$ R staining in the same section nor combined NG2 immunostaining and $\mathrm{PDGF} \alpha \mathrm{R}$ in situ hybridization.

\section{NG2 cells in chronic MS lesions}

Our studies identified NG2 cells in all of the chronic MS lesions that were analyzed. However, their distribution and morphology varied from lesion to lesion. These data suggest that NG2 cells consist of a dynamic population of cells that respond to CNS injury. The dramatic reduction of NG2 cell density in many lesions supports death or the removal of NG2 cells that were originally present in the lesion area. Whether the remaining cells existed in 
the lesion area before demyelination, migrated to the lesion, or were generated by a CNS stem cell is unknown.

NG2 staining intensity varied in different brains and in different areas from the same brain. Within individual brains NG2 staining intensity was greatest on elongated cells in MS lesions. Next in NG2 staining intensity were cells located at the outside border of MS lesions, followed by cells not associated with MS lesions. NG2 staining intensity in normal-appearing tissue also varied between MS brains. NG2 cells in brains with a generalized parenchymal microglia activation, identified by increased MHC class II, stained more intensely than NG2 cells in brains with weaker microglia class II staining. These results suggest an upregulation of NG2 expression by parenchymal cells in MS lesions and some MS brains. NG2 expression may be affected by local and generalized CNS environments that vary according to immune system activation, bloodbrain barrier changes, genetic background, or local cytokine production.

In contrast to white matter lesions, the distribution and morphology of NG2-positive cells in demyelinated and normal cerebral cortex are similar. Infiltrating leukocytes are rare in cortical MS lesions. If inflammation has a role in NG2 cell activation as described in experimental autoimmune encephalomyelitis (EAE) (Nishiyama et al., 1997), reduced inflammation may explain the normal appearance of NG2 cells in gray matter lesions. Another interesting observation was the detection of stellate-shaped NG2 cells in all of the demyelinated subependymal locations. These cells persisted in lesions dominated by elongated NG2 cells. Their proximity to a germinal matrix zone is of interest and may reflect the ability of subventricular progenitor cells to repopulate adjacent demyelinated areas with stellate NG2 cells.

\section{Are NG2 cells present in acute MS lesions?}

Two acute inflammatory demyelinating lesions from different patients were analyzed for NG2 cells. Although caution must be taken in generalizing these data because of the small number, NG2-positive cells were not detected within the area of demyelination. NG2 cells were detected at the border of these lesions and in adjacent normal-appearing white matter, so we consider it unlikely that they were undetected for technical reasons. The loss of NG2 immunoreactivity is not unique to acute MS lesions because NG2 cells were not detected in white and gray matter infiltrated by a B-cell lymphoma nor in an acute inflammatory lesion from an SSPE brain. It is possible, however, that NG2 is removed enzymatically or downregulated in these inflamed lesions. Indirect evidence supporting the survival of NG2 cells in some acute lesions includes extensive remyelination during early stages of MS. The MS lesions that were analyzed in the present study did not display extensive remyelination, so our studies have not tested this hypothesis directly. Detection of NG2 cells in chronic MS lesions indicates that NG2 cells either survive or repopulate acute MS lesions. NG2 cells were detected in acute EAE lesions and considered "reactive" or "activated" on the basis of their elongated shape and increased NG2 staining (Nishiyama et al., 1997). The acute EAE lesions were analyzed before frank demyelination and were much younger than the acute MS lesions reported here. Therefore, direct comparisons of changes in NG2 cells cannot be drawn.

\section{p75 ${ }^{\text {NTR }}$ expression in MS lesions}

p $75^{\mathrm{NTR}}$ is a member of the neurotrophin receptor (NTR) family and can play a critical role in neural cell survival and death by activating intracellular signaling pathways. $\mathrm{p} 75^{\mathrm{NTR}}$ and Trk receptors are coreceptors for the neurotrophins (Carter and Lewin, 1997). Oligodendrocytes in vitro can express both $\mathrm{p} 75^{\mathrm{NTR}}$ and TrkA (Cohen et al., 1996; Althaus et al., 1997) and in a liganddependent manner can activate the NFB pathway and promote cell survival (Yoon et al., 1998). p $75^{\mathrm{NTR}}$ also may function independently of TrkA and induce apoptosis via activation of its cytoplasmic "death domain" and sphingomyelin hydrolysis (Dobrowsky et al., 1994). NGF induced apoptosis in p $75^{\mathrm{NTR}^{\mathrm{T}}}$-positive, TrkAnegative rodent oligodendrocytes maintained in vitro (Casaccia-
Bonnefil et al., 1996), but not in oligodendrocytes isolated from adult human brain (Ladiwala et al., 1998). These studies suggest that $\mathrm{p} 75^{\mathrm{NTR}}$ function is bipotential and is modulated by the presence or absence of other signaling molecules.

The present study investigated the distribution of $p 75^{\text {NTR }}$ positive cells in MS tissues. A subpopulation of oligodendrocytes and some elongated NG2-positive cells were p75 ${ }^{\mathrm{NTR}}$-positive. Nonmyelinating Schwann cells express $\mathrm{p} 75^{\mathrm{NTR}}$, but not detectable levels of NG2. Schwann cells can remyelinate some axons in MS lesions, particularly near peripheral nerve entry zones in the spinal cord (Itoyama et al., 1983). The p75 NTR or NG2-positive elongated cells did not express detectable levels of Schwann cell markers, and remyelination by Schwann cells was not detected in the brain lesion that was analyzed in the present study. p75 NTR also was detected in HNK-1-positive cells in six of seven MS lesions (Dowling et al., 1997). HNK-1 is expressed by oligodendrocyte progenitors, oligodendrocytes, and human natural killer cells. To investigate whether p75 NTR expression was associated with apoptosis in our tissue, we performed $\mathrm{p} 75^{\mathrm{NTR}}$ immunocytochemistry and TUNEL on single sections from three active, nine chronic active, and four chronic inactive lesions. Although both $\mathrm{p} 75^{\mathrm{NTR}}$-positive and TUNELpositive cells were abundant in the active and chronic active lesions, dual labeling was not detected. Most TUNEL-positive cells were small and round, many were part of or located near perivascular cuffs, and in agreement with previous studies (Bonetti and Raine, 1997) they were identified as leukocytes (data not shown). In contrast to these results, $40-50 \%$ of TUNEL-positive cells in six MS lesions were reported p75 ${ }^{\mathrm{NTR}}$-positive (Dowling et al., 1999). Although our data do not support apoptosis of oligodendrocyte lineage cells as a generalized phenomena, it may occur in select MS lesions or in subpopulations of patients (Lucchinetti et al., 1996; Dowling et al., 1999). The chronic nature of MS makes it unlikely that significant numbers of TUNEL-positive oligodendrocyte lineage cells will be detected routinely in MS lesions. The role of $\mathrm{p} 75^{\mathrm{NTR}}$ in oligodendrocytes and NG2 cells in MS lesions remains to be elucidated and also may signal cell survival.

\section{Summary}

The present study unequivocally identifies a population of NG2positive cells in the adult human brain that appears as abundant but distinct from astrocytes, oligodendrocytes, and microglia. NG2 cells are precursors for oligodendrocytes during development (Levine et al., 1993; Nishiyama et al., 1996b; Trapp et al., 1997), and when cells with phenotypic characteristics of NG2 cells are isolated from adult mammalian brain, they give rise to mature oligodendrocytes in vitro (Ffrench-Constant and Raff, 1986; Wolswijk and Noble, 1989). The detection of NG2-positive cells in MS lesions raises the possibility that they give rise to remyelinating oligodendrocytes in MS lesions. This hypothesis, however, remains to be substantiated. In either event, further characterization of NG2 cells in MS, other human diseases, and animal models of human disease is warranted and needed to understand better the function of this dynamic cell population.

\section{REFERENCES}

Althaus HH, Hempel R, Kloppner S, Engel J, Schmidt-Schultz T (1997) Nerve growth factor signal transduction in mature pig oligodendrocytes. J Neurosci Res 50:729-742.

Armstrong RC, Dorn HH, Kufta CV, Friedman E, Dubois-Dalcq ME (1992) Pre-oligodendrocytes from adult human CNS. J Neurosci 12:1538-1547.

Blaschke AJ, Staley K, Chun J (1996) Widespread programmed cell death in proliferative and postmitotic regions of the fetal cerebral cortex. Development 122:1165-1174.

Bö L, Mörk S, Kong PA, Nyland H, Pardo CA, Trapp BD (1994) Detection of MHC class II antigens on macrophages and microglia, but not on astrocytes and endothelia in active multiple sclerosis lesions. J Neuroimmunol 51:135-146.

Bonetti B, Raine CS (1997) Multiple sclerosis: oligodendrocytes display cell death-related molecules in situ but do not undergo apoptosis. Ann Neurol 42:74-84

Butt AM, Duncan A, Hornby MF, Kirvell SL, Hunter A, Levine JM, Berry M (1999) Cells expressing the NG2 antigen contact nodes of Ranvier in adult CNS white matter. Glia 26:84-91. 
Carter B, Lewin GR (1997) Neurotrophins live or let die: does p75 NTR decide? Neuron 18:187-190.

Casaccia-Bonnefil P, Carter BD, Dobrowsky RT, Chao MV (1996) Death of oligodendrocytes mediated by the interaction of nerve growth factor with its receptor p75. Nature 383:716-719.

Cohen R, Marmur R, Norton WT, Mehler MF, Kessler JA (1996) Nerve growth factor and neurotrophin-3 differentially regulate the proliferation and survival of developing rat brain oligodendrocytes. J Neurosci 16:6433-6442.

Dobrowsky RT, Werner MH, Castellino AM, Chao MV, Hannun YA (1994) Activation of the sphingomyelin cycle through the low-affinity neurotrophin receptor. Science 265:1596-1599.

Dowling PC, Husar W, Menonna J (1997) Expression of p75 neurotrophin receptor in multiple sclerosis brain. Neurology 48:A425.

Dowling PC, Ming X, Raval S, Husar W, Casaccia-Bonnefil P, Chao M, Cook S, Blumberg B (1999) Up-regulated p $75^{\mathrm{NTR}}$ neurotrophin receptor on glial cells in MS plaques. Neurology 53:1676-1682.

Ferguson B, Matyszak MK, Esiri MM, Perry VH (1997) Axonal damage in acute multiple sclerosis lesions. Brain 120:393-399.

Ffrench-Constant C, Raff MC (1986) Proliferating bipotential glial progenitor cells in the adult rat optic nerve. Nature 319:499-502.

Gogate N, Verma L, Zhou JM, Milward E, Rusten R, O'Connor M, Kufta C, Hudson L, Dubois-Dalcq M (1994) Plasticity in the adult human oligodendrocyte lineage. J Neurosci 14:4571-4587.

Itoyama Y, Webster HD, Richardson EP, Trapp BD (1983) Schwann cell remyelination of demyelinated axons in spinal cord multiple sclerosis lesions. Ann Neurol 14:339-346.

Keirstead HS, Blakemore WF (1997) Identification of post-mitotic oligodendrocytes incapable of remyelination within the demyelinated adult spinal cord. J Neuropathol Exp Neurol 56:1191-1201.

Ladiwala U, Lachance C, Simoneau SJJ, Bhakar A, Barker PA, Antel JP (1998) p75 neurotrophin receptor expression on adult human oligodendrocytes: signaling without cell death in response to NGF. J Neurosci 18:1297-1304.

Lassman H (1983) Comparative neuropathology of chronic experimental allergic encephalomyelitis and multiple sclerosis. Schriftenr Neurol $25: 1-135$.

Levine JM, Stincone F, Lee YS (1993) Development and differentiation of glial precursor cells in the rat cerebellum. Glia 7:307-321.

Lucchinetti CF, Brück W, Rodriguez M, Lassmann H (1996) Distinct patterns of multiple sclerosis pathology indicates heterogeneity on pathogenesis. Brain Pathol 6:243-258.

Nishiyama A, Lin XH, Giese N, Heldin CH, Stallcup WB (1996a) Interaction between NG2 proteoglycan and PDGF $\alpha$ receptor on $02 \mathrm{~A}$ progenitor cells is required for optimal response to PDGF. J Neurosci Res 43:315-330.

Nishiyama A, Lin XH, Giese N, Heldin CH, Stallcup WB (1996b) Colocalization of NG2 proteoglycan and PDGF $\alpha$ receptor on $02 \mathrm{~A}$ progenitor cells in the developing rat brain. J Neurosci Res 43:299-314.

Nishiyama A, Yu M, Drazba JA, Tuohy VK (1997) Normal and reactive $\mathrm{NG} 2^{+}$glial cells are distinct from resting and activated microglia. J Neurosci Res 48:299-312.

Nishiyama A, Chang A, Trapp BD (1999) $\mathrm{NG}^{+}$glial cells: a novel glial cell population in the adult brain. $J$ Neuropathol Exp Neurol 58:1113-1121.

Ong WY, Levine JM (1999) A light and electron microscopic study of NG2 chondroitin sulfate proteoglycan-positive oligodendrocyte precur- sor cells in the normal and kainate-lesioned rat hippocampus. Neuroscience 92:83-95.

Ozawa K, Suchanek G, Breitschopf H, Brück W, Budka H, Jellinger K, Lassmann H (1994) Patterns of oligodendroglia pathology in multiple sclerosis. Brain 117:1311-1322.

Prineas JW, McDonald WI (1997) Demyelinating diseases. In: Greenfield's neuropathology (Graham DI, Lantos PL, eds), pp 813-896. New York: Oxford UP.

Prineas JW, Kwon EE, Goldenberg PZ, Ilyas AA, Quarles RH, Benjamins JA, Sprinkle TJ (1989) Multiple sclerosis: oligodendrocyte proliferation and differentiation in fresh lesions. Lab Invest 61:489-503.

Pringle NP, Richardson WD (1993) A singularity of PDGF alphareceptor expression in the dorsoventral axis of the neural tube may define the origin of the oligodendrocyte lineage. Development 117:525-533.

Raine CS (1994) Multiple sclerosis: immune system molecule expression in the central nervous system. J Neuropathol Exp Neurol 53:328-337.

Raine CS, Scheinberg I, Waltz JM (1981) Multiple sclerosis: oligodendrocyte survival and proliferation in an active established lesion. Lab Invest 45:534-546.

Reynolds R, Hardy R (1997) Oligodendroglial progenitors labeled with the $\mathrm{O} 4$ antibody persist in the adult rat cerebral cortex in vivo. J Neurosci Res 47:455-470.

Richardson WD, Pringle N, Mosley MJ, Westermark B, Dubois-Dalcq M (1988) A role for platelet-derived growth factor in normal gliogenesis in the central nervous system. Cell 53:309-319.

Scolding N, Franklin R, Stevens S, Heldin C-H, Compston A, Newcombe J (1998) Oligodendrocyte progenitors are present in the normal adult human CNS and in the lesions of multiple sclerosis. Brain 121:2221-2228.

Shi J, Marinovich A, Barres BA (1998) Purification and characterization of adult oligodendrocyte precursor cells from the rat optic nerve. J Neurosci 18:4627-4636.

Stallcup WB, Beasley L (1987) Bipotential glial precursor cells of the optic nerve express the NG2 proteoglycan. J Neurosci 7:2737-2744.

Trapp BD, McIntyre LJ, Quarles RH, Sternberger NH, Webster HD (1979) Immunocytochemical localization of rat peripheral nervous system myelin proteins: P2 protein is not a component of all peripheral nervous system myelin sheaths. Proc Natl Acad Sci USA 76:3552-3556.

Trapp BD, Nishiyama A, Cheng D, Macklin W (1997) Differentiation and death of premyelinating oligodendrocytes in developing rodent brain. J Cell Biol 137:459-468.

Trapp BD, Peterson J, Ransohoff RM, Rudick R, Mörk S, Bö L (1998) Axonal transection in multiple sclerosis lesions. N Engl J Med 338:278-285.

Trapp BD, Ransohoff RM, Fisher E, Rudick RA (1999) Neurodegeneration in multiple sclerosis: relationship to neurological disability. Neuroscientist $5: 48-57$

Waxman SG (1996) Pathophysiology of demyelinated and remyelinated axons. In: Handbook of multiple sclerosis (Cook SD, ed), pp 257-294. New York: Dekker.

Wolswijk G (1998) Chronic stage multiple sclerosis lesions contain a relatively quiescent population of oligodendrocyte precursor cells. J Neurosci 18:601-609.

Wolswijk G, Noble M (1989) Identification of an adult-specific glial progenitor cell. Development 105:387-400.

Yoon SO, Casaccia-Bonnefil P, Carter B, Chao MV (1998) Competitive signaling between TrkA and p75 nerve growth factor receptors determines cell survival. J Neurosci 18:3273-3281. 